\title{
Kidnapping In Nigeria, The Impact On Girl-Child Education
}

\author{
Josephine Azuka Onyido (PhD) \\ Department Of Educational Foundations \\ Faculty Of Education, University Of Port Harcourt
}

\begin{abstract}
Kidnapping is a serious injustice to the human race as a result of its impact on the society. Once seen as a foreign problem, kidnapping today has spread across every part of the country threatening its national peace and development. In recent times, there has been an upsurge in the abduction of the girl-child and the recent abduction of school girls in Dapchi in Yobe state clearly comes to mind. This paper therefore seeks to critically analyze the impact kidnapping has on the education of the girl-child in Nigeria. It highlights the importance of the girl-child in national development and establishes that kidnapping can be as a result of agitation, financial or terroristic intent and the resultant impact it has on the emotional state of the girl-child while concluding that Nigerians educational system has seriously been impacted by kidnapping activities particularly in the northern parts of Nigeria. It recommends a number of solutions which include that; stiffer penalties should be imposed on kidnappers, the government should adopt poverty alleviation and empowerment programmes aimed at creating avenues for entrepreneurship, non-governmental bodies in partnership with the government should organize sensitization programmes aimed at discouraging kidnapping and highlighting the impact kidnapping has on victims, Security agencies should be adequately funded and equipped to continue the fight to rid Nigeria of terrorist elements, legislations that aim to empower and encourage gender equity in the Nigerian society should be introduced to encourage the enrolment of the girl-child in schools.
\end{abstract}

Keywords: Kidnapping, Education, Girl Child

\section{INTRODUCTION}

The Nigerian state today is currently riddled with endemic corruption, terrorism, ritualism, extra judicial killings, kidnapping, religious and electoral violence across the nation. These challenges have had disastrous impact on the economy, security and human lives. Scholars have established the devastating effects these issues of insecurity have placed on the economic development of countries and have called for the fight against insecurity to be strengthened.

Deaths from extra judicial killings, religious, terrorist related activities and ritualism have become a frequent aspect of the news on most Nigerian news channels and one of the disturbing plagues currently challenging the Nigerian state is kidnapping and ransome seeking. The abduction of the father of former Super Eagles captain, Mikel Obi, the wife of the central bank governor, Mrs Magaret Emefiele, Oba Oniba of Ibaland in Lagos are some of the several high cases of kidnapping in the country.

Once seen as a foreign problem, today the practice of kidnapping and ransom seeking has spread across the country affecting everyone irrespective of the societal class, threatening national peace and security of the country (Dodo, 2010; Ibrahim \& Mukhtar, 2017).

It is estimated that between 2008 and 2010, the Nigerian police force recorded 887 abduction cases across the country (Action on Armed Violence, 2013). The Niger-delta region has been immensely affected by this disturbing trend. According to Hazen \& Horner, kidnapping in the 
region has reached an alarming level. In recent times however, the kidnapping of school girls have been on the increase in the country as is evident in the kidnapping of 250 girls in Chibok in Borno state and 110 girls in Dapchi in Yobe state. This paper therefore seeks to critically analyze the kidnapping of girls in Nigeria and its impact on girl-child education.

\section{THE CONCEPT OF KIDNAPPING}

The term kidnapping can be traced back to the $17^{\text {th }}$ century United Kingdom, where infants "kids" of wealthy families were "napped" while at sleep for ransom (Tzanelli, 2006; Ibrahim \& Mukhtar, 2007). As such, it is a criminally induced behavior that is not entirely a new societal challenge. Kidnapping can be defined as the process of abducting an individual or group of individuals with a view to achieving a desired objective (Ngwama, 2014). According to Fage \& Alabi (2017) it involves the application of force to take human beings as hostages to achieve a particular aim. Furthermore, it can be defined as the act of forcefully seizing and detaining an individual by unwanted act on the part of the victim.

Proponents have highlighted that the Kidnapping can originate from the need to agitate for economic empowerment, human and environmental right, political liberty, terrorist intent.

In the Niger-delta region for instance, kidnapping was targeted at foreigners from European, American, and Asian countries to raise awareness on the economic and environment conditions of the region (Ani \& Nweke, 2014). However, kidnapping may be engineered by groups agitating for political liberty such as the FARC rebel group of Columbia (Rubio, 2004). Kidnapping can also be induced by terroristic intent which can be seen in the kidnap of the school girls in Chibok town on the $14^{\text {th }}$ April, 2014 by members of Boko Haram.

Scholars have highlighted that, no matter the intentions of the kidnappers, the terror impact on their victims cannot be overlooked (Ene, 2018). Furthermore, these kidnapping used to generate awareness of the Nigerian government and the world to the environmental impact of oil exploration on the region soon became used for financial exploitation (Ani \& Nweke, 2014). According to a former Inspector General of Police in Nigeria, an estimated 100 million USD was paid as ransom to abductors between 2006 and 2009 (Ene, 2018) showing a worrisome rise in the level of kidnapping in the country. This therefore highlights the level of decay present in today's society and the consequent impact it has on every aspect of the society particularly the girl-child.

\section{THE CONCEPT OF GIRL-CHILD}

Over the years, scholars have continued to debate on the concept of the girl child. With gender equality being advocated by international and domestic bodies, the girl-child can be described as a female child who is under the supervision of adults who may be her relations, parents or guardians (Offorma, 2009). They are biological female off springs that are between the ages of 0 and 18 years. In essence, the period that includes their infancy " $0-5$ " years as well as their early (6-12 years) and late adolescent (12-18 years) phases of development respectively (Ponte, 2006).

They are at this stage of development easily impressionable by their environment and the adults around them, they therefore model their attitude around the observations they visualize in their everyday life consequently impacting and shaping their emotional and mental development (Atama, 2012; Kobani \& Nkpolu, 2014). 
The girl-child thus is a young female who would eventually grow into a woman and marry and as such they are conditioned to fend after the young ones at home and take up the responsibility of preparing dishes (Onyido \& Osigwe, 2017).

In the African society in particular where the patriarchal belief and practice still continues to be promoted. According to Enejere (1991) there exists the belief that women are second class citizens. Hence, the girl child continues to face discrimination in education, marriage and job opportunities to mention but a few. This has been further promoted by religious, economic and cultural reasons and has therefore placed the girl-child and females in general at a disadvantage with regard to playing an active role in the society today.

For instance, the situation where the rights of the girl-child have been repeatedly violated through early marriage has seen millions of girls drop out of school due to pregnancy (Sanni, 2015). It is estimated that in developing communities 2.5 million girls under the age of 16 have experienced child marriage (WHO, 2013) and this clearly shows the impact discrimination has had on the girl child and the society at large. As women clearly make up a significant proportion of the population and their economic and societal significance cannot be overlooked. It is estimated that about $49 \%$ of the population in Nigeria are women which accounts for approximately 80.2 million of the entire population (Onyido \& Brambaifa, 2018). Quoting Abbagana (2013) "if you teach a man you teach an individual but if you teach a woman you teach a family and the whole nation".

Women are therefore responsible for 50-60 percent of the processes that are involved in the processing of food, livestock farming, industrial processing and production. As such, their impact on the development of any country if empowered must be taken into account. This development however, will not be complete if the quality of education is sub-standard or affected by challenges such as insecurity, failure to provide infrastructures by government or natural disasters.

Insecurity has been identified as a significant challenge to the development of any society as a result of its inherent impact on educational sector and the society at large. As such, its impact on the educational sector must therefore be critically analyzed.

\section{EDUCATION}

The importance of education in societal development cannot be overemphasized. No country can meet its true potential if the educational sector is not developed. It is an essential tool in ensuring the acquisition of power, prestige, greatness as well as survival of the human race. It is the foundation for nation building (Oyitso \& Olumukoro, 2012).

Education can therefore be defined as the process of developing an individual's mental, social, emotional, spiritual and political intelligence through the provision of requisite information and circumstances that enables this (Kobani \& Nkpolu, 2014). According to Ocho \& Nwangwu (2005) education is the procedure an individual undergoes that make them relevant to the society. Another school of thought proposes that education is the process that sees an individual acquire relevant skills and competencies that enable them actualize their true potentials and reach self-actualization (Onyido \& Osigwe, 2017). Bulut \& Bars (2013) postulates that it aids in the preservation, transmission and enhancing cultures across societies.

It can therefore be seen that education is an essential aspect of human and capital development (Apple, 2011) and holds the key to unlocking the potentials of the society through 
empowerment of its populace (Onyido and Osigwe, 2017). It is an inalienable right of every person (Obinaju, 2014).

In present day Nigeria, the women have overcome the limitations of the past and have made giant strides in terms of politics, education, health, sports and business. As such, they have since moved from being reserved to the kitchen to become chairwomen of boards of companies. This can be attributed to the increasing educational opportunities being offered to the girl-child in today's society.

However, when these educational opportunities are challenged due to insecurity challenges from the kidnapping of school girls and parents. These have consequential implications on national development.

\section{IMPACT OF KIDNAPPING ON THE EDUCATION OF THE GIRL-CHILD}

As the Nigerian society struggles to grasp with the realities of kidnapping, the horrors of the kidnap of school girls remain fresh in the minds of the populace. The case of Leah Shaibu is one of the continuous reminders of the dangers and impact of girl-child kidnapping in Nigeria. This according to Bakwai et al (2014) has seen parents preferring to have their children uneducated than kidnapped or dead. This potential contributes to the over 6 million girls presently out of school (Obahopo \& Arenyeka, 2014).

Murray-Bruce (2013) opines that the falling levels of education can be linked to the insecurity in the country. According to Sanni (2015) the north-east region has been greatly affected by suicide bombing, kidnapping and attacks by militant groups particularly the boko haram group and this is responsible for the north-east part of Nigeria recording the highest levels of girlchild illiteracy in the country.

According to Buba (2015) the children who are kidnapped are subjected to emotional trauma such as rape, child marriage, slavery and torture. The children are also used as human shield and suicide bombers (Sanni, 2015)

These frequent kidnapping of schools girls has seen the attendance in schools across the country drop as a result of fear of such events (Ovuorie, 2015). According to Olugbode (2015) children now live in perpetual fear.

Historically, however participation in education in the northern part of Nigeria has been lower than the southern parts of Nigeria and this can be attributed to a number of reasons such as religion, culture and the perception that the western influenced education is contrary to the Islamic beliefs (Okobiah, 2002). This has been worsened by the increasing case of girl-child kidnapping in the region.

It can therefore be deduced that the resultant effect of kidnapping on the education of the girlchild include low turn-out as well as increasing numbers of illiterates thereby limiting their possible contribution to societal, economic and political growth.

\section{CONCLUSION}

The importance of Girl-child education lies in the proposition that women are foundation of any society. In the sense that despite the discrimination they face in the society, they remain major stakeholders in the agricultural, educational and manufacturing industries. As the saying goes "when you educate a woman you educate a nation" this clearly exemplifies the importance of the girl child to the nation. 
Developed countries such as United Kingdom and Germany have long identified the contribution of women to national development and this has clearly impacted their level of development economically and politically. Today these two nations are ruled by women. There is therefore need for the empowerment of the girl-child through education if Nigeria is to experience sustainable development.

It is therefore, worrisome to observe that kidnapping and terror related activities which begun as an outlet for the agitation for the Niger-Deltans has since spread across the country becoming a terror oriented and profit making venture.

The paper establishes that this cases of kidnapping has experienced an increase in case of girl child abduction who are used as sex slaves, shields, suicide bombers and has seen the reduction in the enrolment in schools as well as increased number of uneducated women in the society which has consequential implications on national development in general.

\section{RECOMMENDATIONS}

- Stiffer penalties should be imposed for kidnappers

- The government should adopt poverty alleviation and empowerment programmes aimed at creating avenues for entrepreneurship.

- Non-government agencies in partnership with the government should organize sensitization programmes aimed at discouraging kidnapping and highlighting the impact kidnapping has on victims.

- Non-government bodies in collaboration with government should try to address the emotional trauma victims of these hideous acts may experience by offering assistance to them in their emotional recovery.

- Security agencies should be adequately funded and equipped to continue the fight to rid Nigeria of terrorist elements.

- Legislations that aim to empower and encourage gender equity in the Nigerian society should be introduced to encourage the enrolment of the girl-child in schools.

- Government should tackle the root problems encouraging the practice of such illegal acts such as job creation, perceived marginalization, insecurity,

\section{References}

Abbagana, K. K. (2013). Female-child education: a critical issue for national development in Nigeria. Journal of Education and Leadership Development, 5(2), 1-8.

Action on Armed Violence (2013). Mapping efforts against armed violence in Nigeria. Interim Report by the AOAV and National Working Group on Armed Violence (NWGAM)

Ani, K. J., \& Nweke, E. N. (2014). Curbing Kidnapping in Nigeria: An Exploration of Strategic Peace Building Tools. Africa's Public Service Delivery \& Performance Review, 2(1), 111-133

Apple, M. W. (2011). Global crises, social justice, and teacher education. Journal of Teacher Education, 62(2), 222234.

Atama, G. C. (2012). Girl-child education: A challenge for sustainable development in Nigeria. Mediterranean Journal of Social Sciences, 3, 14.

Bakwai, B.; Yisa, H. M. \& Jega, M. A. (2014). Insecurity in northern Nigeria and girls participation in basic primary schools: planning for peace culture. In N.M. Abraham, D. O. Durosaro, G. G. Kpae, C. E. Edemenang, J. E. Okon and I. O. Odiba (eds.). Managing and Planning Education for Peace Building in Nigeria: Themes and Perspectives (pp. 27-

33). Port Harcourt, Nigeria: University of Port Harcourt Press Ltd.

Bulut, M., \& Bars, M. E. (2013). The Role of Education as a Tool in Transmitting Cultural Stereotypes Words (Formal's): The Case of" Kerem and Asli" Story. Online Submission, 3(15), 57-65.

Buba, I. A. (2015). Terrorism and rape in Nigeria: A cry for justice. Oman Chapter of Arabian Journal of Business and Management Review, 34(2610), 1-12. 
Dodo, A. W. (2010). The causes and remedies of kidnapping in Nigeria. In The Nigerian academic forum, Vol. 19, No. 1, pp. 1-4.

Enejere, E. (1991). Enhancing the Capacity of Women for Participation in Politics: The Electoral Process Approach.

Ene, W. R. (2018). Kidnapping and the Nigerian society: A sociological insight. International Journal of Development and Management Review, 13(1).

Fage, K.S. \& Alabi, D.O. (2017) Nigerian government and politics. Abuja. Basfa Global Concept Ltd.

Ibrahim, B., \& Mukhtar, J. I. (2017). An analysis of the causes and consequences of kidnapping in Nigeria. African Research Review, 11(4), 134-143.

Kobani, D., \& Nkpolu, O. (2014). The impact of girl-child education on community development: A study of Ika Local Government Area of Akwaibom State. Res on Human and Soc Sci, 4(12), 122-128

Ngwama, J. C. (2014). Kidnapping in Nigeria: An emerging social crime and the implications for the labour market. International journal of humanities and social science, 4(1), 133-145.

Obahopo, B. \& Arenyeka, L. (2014). Why the fight for girl-child education in the North must continue. Vanguard Newspaper, Retrieved online on the $13^{\text {th }}$ of January, 2019 from [https://www.vanguardngr.com/2014/05/fightgirl-child-education-north-must-continue/]

Ocho, L. O., \& Nwangwu, I. O. (2005). Issues and Concerns in Education \& Life. Institute for Development Studies.

Offorma, G. C. (2009, July). Girl-child education in Africa. In Keynote Address Presented at the Conference of University WOMWNE of Africa Held in Lagos, Nigeria, 16th-19th July.

Olugbode, M. (2015). Children Now Live in Fear in Northeastern Nigeria. Retrieved online on the $13^{\text {th }}$ of January, 2019 from [https://allafrica.com/stories/201501070078.html]

Onyido, J. A., \& Osigwe, J. N. Girl-Child Education: The Key For Value Re-Orientation And Nation Building. Retrieved on the 13th of January 2019 from [http://www.globalacademicgroup.com/journals/academic\%20excellence\%20/girl-child\%20education.pdf\}

Onyido, J. A., \& Brambaifa, A. P. (2011). The Educated Women in Nigeria: An Evaluation. The Nigerian Journal of Research and Production Volume, 18(1).

Onyido, J. A., \& Brambaifa, A. P. (2018). Girl-Child Marriage in the Nigerian Society, Causes, Impacts and Mitigating Strategies. World Journal of Social Sciences and Humanities. 2018; 4(2):104-110. doi: 10.12691/wjssh-4-2-6

Oyitso, M., \& Olomukoro, C. O. (2012). Enhancing women's development through literacy education in nigeria. Review of European Studies, 4(4), 66.

Ponte, B. N. (2006, September). Girl-child Empowerment: A Challenge for all. In United Nations Division for the Advancement of Women (DAW) in Collaboration with UNICEF Expert Group Meeting Eliminating of all Forms of Discrimination and Violence Against the Girl-Child. UNICEF Innocenti Research Centre Florence, Italy (pp. 25-28).

Rubio, M. (2004, August). Kidnapping and armed conflict in Colombia. In conference, Techniques of Violence in Civil War, PRIO, Oslo, Norway.

Sanni, O. B. (2015). Effects Of Insecurity And Challenges On Females' education In Nigeria. African Journal for the Psychological Studies of Social Issues, 18(3), 49-56.

Tzanelli, R. (2006). Capitalizing on value: Towards a sociological understanding of kidnapping. Sociology, 40(5), 929-947.

World Health Organization (2013). Child Marriage. Retrieved [Online], on the 23 ${ }^{\text {rd }}$ of December, 2018. From [http://www.who.int/mediacentre/news/releases/2013/child_marriage_20130307/en/]

Ovuorie, T. (2015). 'Northern States have Nigeria's worst girl-child education - Report. https://www.premiumtimesng.com/news/146560-northern-states-nigerias-worst-girl-child-educationreport.html

Okobiah, O. S. (2002). The Educational Imbalance Between the Northern and Southern States of Nigeria: A Redirection of Educational Policies" Inaugural Lecture Series. Delta State University, Abraka, 13th March. 